\title{
Circulating insulin-like growth factor $I$ in Type 1 (insulin-dependent) diabetic patients with retinopathy
}

\author{
P. Arner ${ }^{1,3}$, S. Sjöberg ${ }^{1}$, M.Gjötterberg ${ }^{2}$ and A. Skottner ${ }^{4}$ \\ Departments of ${ }^{1}$ Medicine and ${ }^{2}$ Ophthalmology and the ${ }^{3}$ Research Center, Karolinska Institute, Huddinge Hospital and \\ ${ }^{4}$ Kabi Vitrum Ltd, Stockholm, Sweden.
}

\begin{abstract}
Summary. The relationship between insulin-like growth factor I (IGF I) and diabetic retinopathy was investigated. This somatomedin circulates bound to at least two large carrier proteins with molecular weights of approximately 150,000 and 35,000 . Total and protein binding profiles of insulin-like growth factor I were determined in the serum of 18 patients who had had Type 1 (insulin-dependent) diabetes for 15-20 years, but had no signs of nephropathy and a similar degree of mild subclinical neuropathy. Nine had preproliferative or proliferative retinopathy and 9 had little or no background retinopathy but there was no difference in diabetes duration, insulin doses or glycaemic control between the two groups. In the latter group, the amounts of the somatomedin $I$ and the serum profiles were similar to those in 9 healthy control subjects. In patients with advanced retinopathy, however, binding of insulin-like growth factor I to the carrier proteins was significantly altered. Binding to the low molecular weight protein
\end{abstract}

increased to $140 \%$ whereas binding to the large molecular weight protein decreased to $70 \%$ of the normal level. In the latter Type 1 diabetic patients total serum insulin-like growth factor I was decreased to $60 \%$ of the normal level $(p<0.02)$. When the alteration in serum profile was adjusted for, the level of somatomedin associated with the small carrier complex was normal whereas that associated with the large carrier complex was reduced by almost $60 \%$ in Type 1 diabetic patients with retinopathy. It is proposed that the total circulating somatomedin level is low in advanced diabetic retinopathy. Furthermore, changes in the carrier binding of insulin-like growth factor I rather than in the total circulating level of the somatomedin may be involved in diabetic retinopathy.

Key words: Somatomedin; carrier protein, diabetes complications.
Proliferative retinopathy is a major problem in the management of Type 1 (insulin-dependent) diabetes mellitus, since bleeding from newly-formed retinal vessels into the vitreous may cause severe impairment of vision. The pathophysiology of diabetic retinopathy is largely unknown, but it was frequently been proposed that growth hormone plays a role.

Several effects which have previously been attributed to growth hormone are now considered to be mediated by secondary growth factors or somatomedins, such as the insulin-like growth factors I and II (IGF I, IGF II). The results of studies of both these growth factors in diabetes patients with retinopathy have been conflicting. Although there seems to be no association between circulating IGF II and diabetic retinopathy [1], both increased [1,2] and normal [3-5] serum levels of IGF I have been found in some diabetic patients with exudative or proliferative retinopathy. In the previous studies, however, only the total levels of circulating IGF I were deter- mined [1-5]. Somatomedins are unique among polypeptide hormones and parahormones since only a small free fraction is present in the circulation; most are bound to carrier proteins in the blood [6]. Two different IGF I-protein binding complexes have been identified in human serum [6]. A large molecular complex with molecular weight about 150 kilodaltons $(150 \mathrm{Kd})$ is formed by the binding of IGF to a large acid-sensitive protein composed of subunits. A smaller complex (about $40 \mathrm{Kd}$ ) is formed by IGF and an acid-stable carrier protein. These circulating complexes appear to function as a reservoir for somatomedins, since they are not stored in other tissues [6]. Recent studies of the IGF-carrier protein complexes reveal that they are under physiological control which ultimately aims at delivering IGF to its specific target cells [6, 7]. The $40 \mathrm{Kd}$-IGF I complex may be of particular importance for diabetic retinopathy. This complex, but not the $150 \mathrm{Kd}$ complex, is present in the vitreous [8]. 
In the present study we examined the serum binding profiles as well as the total circulating IGF I in patients with a 15-20-year history of Type 1 diabetes. At this time the maximum incidence of advanced retinopathy usually occurs [9]. Evidence is available for demonstrating a relationship between this eye complication and alterations in the IGF I-carrier protein complexes.

\section{Subjects and methods}

Study population. The study comprised of 9 healthy drug-free control subjects and 25 patients with insulin-treated Type 1 diabetes. The groups were matched for age, sex and body weight. The diabetic patients were matched for insulin doses, glycaemic control and duration of the disease. The duration of diabetes ranged from 15 to 20 years. There were no symptoms of nephropathy or neuropathy in any of the patients. None of the Type 1 diabetic patients had residual insulin production, as evidenced by the absence of detectable levels of C-peptide in the urine. All of them injected medium-acting insulin (once or twice daily) and short-acting insulin (one to three times a day). All Type 1 diabetic patients were otherwise healthy and drug-free. All of them had normal blood pressure. After breakfast, between 09.00 and 10.00 hours, a venous blood sample was taken for determinations of serum creatinine, $\mathrm{HbA}_{1 \mathrm{c}}$ and IGF I. The study was approved by the Huddinge Hospital's Ethics Committee.

Ophthalmological examination. Each Type 1 diabetic patient was examined with ophthalmoscopy, biomicroscopy and fluoroscein angiography. A score for retinopathy findings based on these investigations, which has previously been described in detail [10], was used for the diagnosis and qualitative evaluation of diabetic retinopathy. The Type 1 diabetic patients were placed in the following groups according to their total score. Score $0=$ no signs of retinopathy, score 1-3=minimal background retinopathy, score 4-15=definite retinopathy but no signs of proliferations, score $16=$ proliferative retinopathy.

After the ophthalmological examination all Type 1 diabetic patients underwent nephrological and neurological examinations (see below). All patients with disturbed kidney function (significant microalbuminuria and/or abnormally low chromium - EDTA clearance) were excluded from the study, since it is well established that the circulating somatomedin level is dependent upon kidney function [7]. Of the remaining patients nine scoring $0-3$ formed one group. Seven Type 1 diabetic patients scoring [5-8] points each (preproliferative retinopathy) plus two Type 1 diabetic patients with proliferative retinopathy formed a second group.

Nephrological and neurological examinations. Microalbuminuria was determined by the hospital's routine chemistry laboratory on 24-h urine samples. A value above $1.2 \mathrm{mg} / \mathrm{h}$ was considered to be significant albuminuria. Chromium-EDTA clearance was performed by the hospital's routine physiological laboratory. A value below $82 \mathrm{ml} \cdot \mathrm{min}^{-1} \cdot 1.73 \mathrm{~m}^{2}$ was considered to be pathological.

The neurophysiological examination was done at the hospital's routine neurophysiological laboratory. Electroneurography was performed on the median, peroneal and sural nerves on one side. On the basis of these nerve conduction parameters a neuropathy index was calculated as described previously in detail [10]. A significant deviation from normal corresponds to an index of \pm 0.63 .

Serum binding profiles of IGFI. Recombinant human IGF I produced in yeast from Kabi Vitrum AB (Stockholm, Sweden) was labelled with ${ }^{125}$ iodine $\left({ }^{125} \mathrm{I}\right)$ by the lactoperoxidase method [11]. The tracer was purified on an ion exchange column [12]. Approximately $70,000 \mathrm{cpm}$ of the iodinated IGF I in a total volume of $1 \mathrm{ml}$ Tris $\mathrm{HCl}$ $(0.05 \mathrm{~mol} / \mathrm{l})$ was added to $1 \mathrm{ml}$ of the serum sample and incubated overnight at $+4^{\circ} \mathrm{C}$. Previous methodological experiments showed that equilibrium between ${ }^{125}$ I-IGF I and serum was reached after $5 \mathrm{~h}$ of incubation under the present conditions. After the incubation the sample (total volume $2 \mathrm{ml}$ ) was gel-filtered on a calibrated Sephadex G200 column (K16/100, Pharmacia AB, Uppsala, Sweden), equilibrated in Tris $\mathrm{HCl}(0.05 \mathrm{~mol} / \mathrm{l}, \mathrm{pH} 7.5)$. The dimension of the column was $0.1 \times 0.016 \mathrm{~m}$. Elution was performed at a flow rate of $8 \mathrm{ml} / \mathrm{h}$, and $1 \mathrm{ml}$ fractions were collected and counted in a gammacounter (LKB-Clini Gamma, Helsinki, Finland). Counts were plotted against the fractions to obtain a serum-binding profile of each serum sample. Three peaks of radioactivity were always obtained, corresponding to molecular weights of $150 \mathrm{Kd}, 40 \mathrm{Kd}$ and $7 \mathrm{Kd}$, respectively. This corresponded to the circulating forms of IGF I (bound to the large and small carrier protein, respectively, and the free fraction) [6]. The same column was used for all experiments. The recovery of added ${ }^{125} \mathrm{I}$-IGF I was $85-90 \%$ in all experiments. The serum samples were grouped in series of 3 including one sample from each study group, and the series were run consecutively. The source of the sample was unknown to the person performing the analyses.

Radioimmunoassay of IGFI. The determination of total circulating IGF I was performed with radioimmunoassay of serum samples using a antibody technique, essentially as described by Furlanetto et al. [13]. The serum samples were subjected to acid-ethanol extraction [14] prior to the assay. This destroys the large carrier protein and

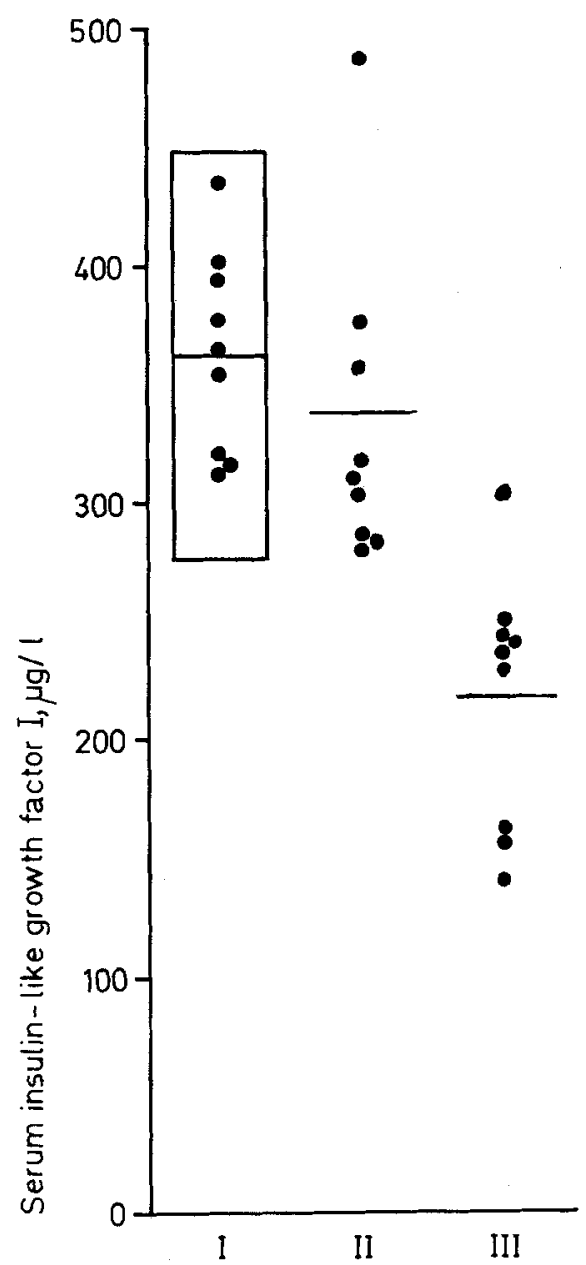

Fig. 1. Individual values for total serum insulin-like growth factor I determined with radioimmunoassay. $\mathrm{I}=$ control subjects, $\mathrm{II}=$ Type 1 (insulin-dependent) diabetic patients with little or no background retinopathy. III = Type 1 diabetic patients with advanced retinopathy. The horizontal lines indicate the mean value in each group. The square indicates $\pm 2 \mathrm{SD}$ of the mean in group I 
Table 1. Clinical data in control subjects and Type 1 (insulin-dependent) diabetic patients

\begin{tabular}{|c|c|c|c|c|c|c|c|c|c|c|c|}
\hline & $\begin{array}{l}\text { Male/ } \\
\text { Female }\end{array}$ & $\begin{array}{l}\text { Age } \\
\text { (years) }\end{array}$ & $\begin{array}{l}\text { Body mass } \\
\text { index } \\
\left(\mathrm{kg} / \mathrm{m}^{2}\right)\end{array}$ & $\begin{array}{l}\text { Diabetes } \\
\text { duration } \\
\text { (years) }\end{array}$ & $\begin{array}{l}\text { Neuropathy } \\
\text { index }\end{array}$ & $\begin{array}{l}\text { Insulin } \\
\text { (U/day) }\end{array}$ & $\begin{array}{l}\text { Micro- } \\
\text { albumin- } \\
\text { uria } \\
(\mathrm{mg} / \mathrm{h})\end{array}$ & $\begin{array}{l}\text { Serum } \\
\text { creatinine } \\
(\mu \mathrm{mol} / \mathrm{l})\end{array}$ & $\begin{array}{l}\text { Chromium- } \\
\text { EDTA } \\
\text { clearance } \\
\left(\mathrm{ml} \cdot \min ^{-1} \text {. }\right. \\
\left.1.73 \mathrm{~m}^{-1}\right)\end{array}$ & $\begin{array}{l}\mathrm{HbA}_{1 \mathrm{c}} \\
(\%)\end{array}$ & $\begin{array}{l}\text { Retinopathy } \\
\text { score, points }\end{array}$ \\
\hline $\begin{array}{l}\text { Control } \\
\text { Subjects }\end{array}$ & $5 / 4$ & $34 \pm 3$ & $24.8 \pm 0.6$ & & & & & $78 \pm 4$ & & $4.2 \pm 0$ & \\
\hline $\begin{array}{l}\text { Type } 1 \\
\text { diabetic patients } \\
\text { with little or no } \\
\text { retinopathy }\end{array}$ & $4 / 5$ & $34 \pm 2$ & $24.2 \pm 0.5$ & $16 \pm 3$ & $0.86 \pm 0.09$ & $51 \pm 4$ & $0.4 \pm 0.1$ & $82 \pm 8$ & $106 \pm 5$ & $7.8 \pm 0.5$ & $1.3 \pm 0.3$ \\
\hline $\begin{array}{l}\text { Type } 1 \\
\text { diabetic patients } \\
\text { with advanced } \\
\text { retinopathy }\end{array}$ & $5 / 4$ & $33 \pm 3$ & $24.7 \pm 0.8$ & $17 \pm 2$ & $0.86 \pm 0.10$ & $52 \pm 5$ & $0.5 \pm 0.1$ & $80 \pm 7$ & $102 \pm 5$ & $8.0 \pm 0.8$ & $9.7 \pm 1.6$ \\
\hline
\end{tabular}

Values are means \pm SEM. Serum creatinine, $\mathrm{HbA}_{1 \mathrm{c}}$ chromium-EDTA clearance and microalbminuria were determined by the routine laboratory procedures

completely dissociates IGF I from this protein. The polyclonal rabbit antibody (K 624) is highly specific for IGF I. Cross-reactivity with IGF II is $<5 \%$, and there is no cross-reactivity with insulin, proinsulin or relaxin [15]. The association constant $(\mathrm{Ka})$ was calculated [16] and found to be $1.49 \times 10^{10} \mathrm{l} / \mathrm{mol}$. This is about 10 times higher than the reported Ka value for binding IGF I to the small carrier protein [17]. Thus, we have no evidence that binding of IGF I to the small molecular weight carrier protein influences the radioimmunoassay. The reference standard used was synthetic unlabelled IGF I, kindly provided by Sumitomo Pharmaceuticals Co, Osaka, Japan. The samples were grouped and analysed in the same way as the serum-binding profiles.

\section{Statistical analysis}

The values presented are means \pm SEM. The Student's unpaired $t$-test and linear regression analysis were used for statistical evaulation of the results.

\section{Results}

Table 1 shows that the two Type 1 diabetic groups were indeed well matched for age, sex, body-weight, diabetes duration, insulin doses. All Type 1 diabetic patients had normal kidney function and Table 1 also shows almost identical values for the two Type 1 diabetic groups regarding microalbuminuria, chromium-EDTA and serum creatinine (all values were normal in all patients). All these factors may influence IGF I and/or the development of retinopathy. Both Type 1 diabetic groups were under average glycaemic control, as evidenced by the $\mathrm{HbA}_{1 \mathrm{c}}$ values. All but five Type 1 diabetic patients had slight evidence of subclinical polyneuropathy (score from -0.73 to -1.68 ). However, the mean neuropathy score value (sligtly elevated) was identical in Type 1 diabetic patients with or without advanced retinopathy (Table 1).

The individual values for total circulating IGF I in the three study groups are shown in Figure 1. The values in the control subjects and diabetic patients with little or no background retinopathy were almost identical. However, the values in the group with advanced retinopathy were markedly lower than those in the other two groups $(p<0.01)$. All but one of the Type 1 diabetic patients with advanced retinopathy had a total IGF I value that was below $2 \mathrm{SD}$ of the mean value for the control group, whereas all but one of the Type 1 diabetic patients with little if any retinopathy had values within this range.

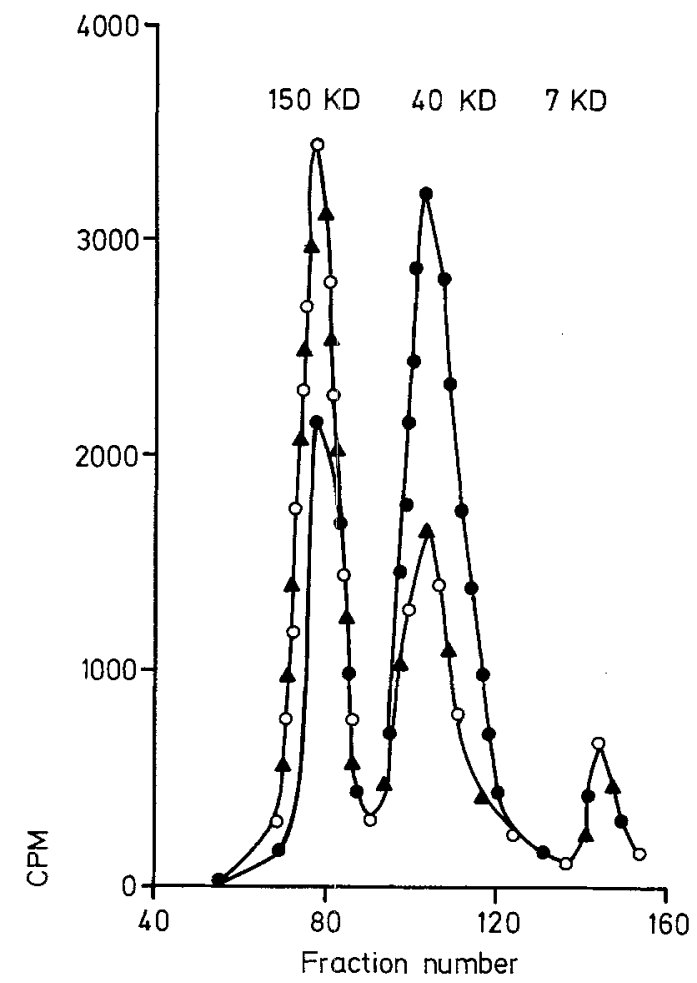

Fig. 2. Serum profiles of insulin-like growth factor I (IGF I) showing carrier-bound and "free" IGF I. After equilibrium with radioactive IGF I, serum samples were separated by gel-filtration. The elution pattern of radioactivity in serum from one representative patient in each group described in Figure 1 is shown. $I=$ open circles; $I I=$ filled triangles; $\mathrm{III}=$ filled circles. The molecular weight $($ kilodaltons $=\mathrm{KD}$ ) of each elution peak is indicated in the graph 


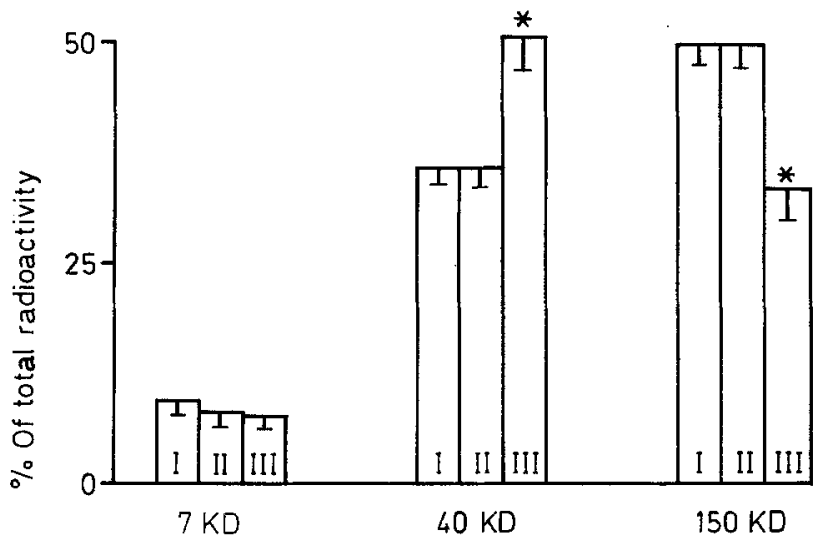

Fig. 3. Distribution of radioactive carrier bound and "free" insulinlike growth factor I in serum of control subjects (I), Type 1 (insulindependent) diabetic patients with little or no background retinopathy (II), and Type 1 diabetic patients with retinopathy (III). The area under the elution peaks 7 kilodaltons (KD), $40 \mathrm{KD}$ and $150 \mathrm{KD}$ showing in Figure 2 was calculated for each individual as percent of the total area of radioactivity. Values are means \pm SEM. An asterix denotes that values for group III differ significantly from the other two groups $(p<0.005)$

The serum profiles of one representative subject in each group are shown in Figure 2. The control subject and the Type 1 diabetic patient with little or no retinopathy showed an almost identical elution pattern of radioactive IGF I. A much larger $150 \mathrm{Kd}$ than $40 \mathrm{Kd}$ peak and a very small $7 \mathrm{Kd}$ (representing "free" IGF I) was found. In contrast, the elution pattern in a Type 1 diabetic patient with advanced retinopathy showed a much larger $40 \mathrm{Kd}$ than $150 \mathrm{Kd}$ peak and a very small $7 \mathrm{Kd}$ peak.

The results of the calculations of the areas under the peaks following gel-filtration are depicted in Figure 3. About $8-10 \%$ of the radioactivity was eluted as $7 \mathrm{Kd}$ IGF I in the three groups. It should be noted that some of this radioactivity may represent fragments of labelled IGF I that is eluted together with "free" IGF I. The distribution of radioactivity between $40 \mathrm{Kd}$ and $150 \mathrm{Kd}$ was identical in control subjects and in Type 1 diabetic patients with little or no retinopathy. In the advanced retinopathy group, on the other hand, the $40 \mathrm{Kd}$ fraction showed a $40 \%$ increase $(p<0.005)$ and the $150 \mathrm{Kd}$ fraction showed a $30 \%$ decrease $(p<0.005)$ as compared to the other two groups.

The results in Figures 2 and 3 were combined in order to estimate how much IGF I that was bound to each carrier complex. IGF I associated with the small carrier protein was similar in the normal and the advanced retinopathy group, 127 and $112 \mu \mathrm{g} / \mathrm{l}$, respectively. In the latter group however, the level of IGF I associated with the large carrier protein was about $40 \%$ of that of the normal group, 75 and $174 \mu \mathrm{g} / 1$, respectively.

A correlation analysis of $\mathbf{H b A}_{1 \mathrm{c}}$ vs total or carrierbound IGFI was performed (figure not shown). Neither in the three groups nor in the total material was there any correlation between these parameters $(r<0.2)$.

\section{Discussion}

This study, in contrast to previous ones, shows decreased total circulating levels of IGF I in Type 1 diabetic patients with advanced retinopathy. Previous investigators have found increased $[1,2]$ or normal $[3$, 5] levels in patients with diabetic retinopathy. However, the difference between present and previous results may be more apparent than real. We have investigated well-defined cases of retinopathy; in several of the earlier studies, patients with large variations in the clinical presentation of diabetes were mixed together. Furthermore, variations in glycaemic control and kidney function or in the duration of diabetes, which may influence circulating IGF I [7, 18, 19] have not been taken into account in previous studies but were well controlled in this study. In fact, we found normal total IGF I in Type 1 diabetic patients who had little or no background diabetic retinopathy but who had a duration of diabetes and glycaemic control almost identical to that in the advanced retinopathy group. Furthermore, kidney function was normal in all Type 1 diabetic patients. The differences between the present and the previous results may also have methodological explanations. The bioassays or radioimmunoassays used previously [1-5] may not have detected all the circulating IGF I. The bioassays may be influenced by inhibitors in serum. Most radioimmunoassays including our method can measure only IGF I that has been dissociated from the carrier protein. However, in our radioommunoassay the large carrier protein was inactivated and the affinity of IGF I to our antibody exceeded that to the small carrier protein. Therefore, it is not likely that significant amounts of IGF I remained bound to the carrier protein in the radioimmunoassay. Thus, we have no indication that the carrier proteins influenced our results. The present data suggest, therefore, that the total circulating level of IGF $I$ is depressed in Type 1 diabetic patients with advanced retinopathy; this is not due to the duration of diabetes, disturbed kidney function or to the glycaemic control. Thus, the notion that an increase in the total circulating IGF $I$ is associated with diabetes retinopathy must be reevaluated. However, it is possible that local tissue levels of IGF I (such as in the eye) may be elevated in advanced retinopathy, since low circulating IGF I may by feedback regulation induce hypersecretion of growth hormone which can have local paracrine IGF I effects.

From the results of the serum profile it is feasible for the first time to evaluate the binding of IGF I to its carrier proteins in diabetic retinopathy. By using the serum profiles we were able to compare changes in the binding protein complexes that may occur in the different individuals. The Type 1 diabetic patients with advanced retinopathy had marked aberrations in the relative proportions of IGF I that bound to the two macromolecular complexes. Binding to the low molecular weight 
form $(40 \mathrm{Kd})$ was increased by about $40 \%$ and binding to the high molecular weight form $(150 \mathrm{Kd})$ was reduced by approximately $30 \%$. It is not likely that gel-filtration distribution of ${ }^{125}$ I-IGF I is different from the distribution of endogenous IGF I in serum. The latter may occur if the binding reaction has not reached equilibrium [13]. However, methodological experiments showed that equilibrium had been reached in the present study.

The mechanisms behind the altered relationship between the two macromolecular complexes in advanced retinopathy are not known. It is, however, possible that changes in the production and degradation of the different somatomedin carrier proteins are involved. Recent studies have shown altered levels of these proteins in Type 1 diabetes [20-22]. Alternatively, the binding reactions between IGF I and the carrier proteins may be altered in advanced retinopathy. It is also possible that the changes in total IGF I and the large carrier protein are directly interrelated. For example the $40 \mathrm{Kd}$ complex is increased in diabetes [22] and the $150 \mathrm{Kd}$ complex is known to decrease in all situations in which IGF I levels are low such as growth hormone defiency, insulin lack and nutrition deficiency $[6,7]$. It should, however, be made clear that the interpretation of serum profiles of IGF I is dependent upon the levels of the two binding proteins (which were not measured).

We have also tried to estimate the absolute levels of the two macromolecule somatomedin complexes. This was done by combining the results with radioimmunoassay and gel-filtration (bearing in mind all methodological problems associated with such calculations). The level of IGF I associated with the $40 \mathrm{Kd}$ complex was in the same range in all 3 groups $(110-130 \mu \mathrm{g} / 1)$, whereas the level associated with the large complex was $60 \%$ reduced in advanced retinopathy. It seems therefore safe to conclude that the serum levels of the $150 \mathrm{Kd}$ somatomedin complex are decreased in diabetic patients with advanced retinopathy.

In theory, the observed abnormality of the level of the circulating $150 \mathrm{Kd}$ IGF complex (and maybe also the $40 \mathrm{Kd}$ complex) in advanced diabetes retinopathy may be associated with factors other than the eye complication. For many reasons, however, this seems unlikely. First, the retinopathy was the sole overt complication of diabetes in our patients. There was a similar mild degree of subclinical neuropathy in both Type 1 diabetic groups and all the investigated Type 1 diabetes patients had normal microalbuminuria and chromiumEDTA clearance. Secondly, Type 1 diabetic patients with fewer, if any retinal changes had a completely normal distribution of the circulating IGF I complexes. Thirdly, factors such as age, insulin doses, diabetes duration and glucose control, which may influence carrier-bound IGF I, could be ruled out since the two Type 1 diabetic groups were closely matched for these factors.
It is not known whether the observed aberrations in the circulating IGF I have a primary or a secondary association with retinopathy. Such questions can be answered only by future prospective studies. Previous studies have focused on an overall increase in the generation of somatomedins. The present results apparently exclude such a role of IGF I in retinopathy (although effects of local overproduction of IGF cannot be excluded). Furthermore, our data suggest that changes in the two circulating IGF I - carrier protein complexes rather than in total circulating IGF I may be involved in diabetic retinopathy. It seems that this eye complication is associated with low levels of the $150 \mathrm{Kd}$ complex and normal or elevated levels of the $40 \mathrm{Kd}$ complex. At present we have no explanation at the molecular level how the somatomedin carrier proteins contribute to the complications of diabetes. Hypothetically, a relative increase in the circulating $40 \mathrm{Kd}$ complex of IGF I may play a role in the development of proliferative retinopathy. Only this protein complex (and not the $150 \mathrm{Kd}$ complex) has been found in the vitreous of eyes from patients with proliferative diabetic retinopathy [8]. Furthermore, it has been shown in vitro that the small binding protein can act as a catalyst and enhance the proliferative effect of IGF I [23].

Acknowledgements. This study was supported by grants from the Swedish Medical Research Council (project 19X-1034), the Swedish Diabetes Association, the Nordic Insulin Foundation, the Hoechst Foundation and the Karolinska Institute. The skillful technical assistance of Mrs. M. Andersson and Mr. J.Holmberg is greatly appreciated.

\section{References}

1. Merimée TJ, Zapf J, Froesch ER (1983) Insulin-like growth factors. Studies in diabetes with and without retinopathy. $\mathrm{N}$ Engl J Med 309: 527-530

2. Ashton JK, Dornan TL, Pocock AW, Turner RC, Bron AJ (1983) Plasma somatomedin activity and diabetic retinopathy. Clin Endocrinol 19: 105-110

3. Cohen MP, Jasty K, Rye DL (1977) Somatomedin in insulin-dependent diabetes mellitus. J Clin Endocrinol Metab 45: 236-239

4. Lamberton RP, Goodman AD, Kassoff A, Rubin CL, Treble DH, Saba TH, Merimée TJ, Dodds WJ (1984) Von Willebrand factor (VIII R:Ag), fibronectin, and insulin-like growth factors I and II in diabetic retinopathy and nephropathy. Diabetes 33: 125-129

5. Salardi S, Cacciari E, Ballardini D, Righetti F, Capelli N, Cicognani A, Zucchini S, Natali G, Tassinari D (1986) Relationships between growth factors (Somatomedin-C and growth hormones) and body development, metabolic control, and retinal changes in children and adolescents with IDDM. Diabetes 35: 832-836

6. Smith GL (1984) Somatomedin carrier proteins. Mol Cell Endocrinol 34: 83-89

7. Phillips LS, Vassilopoulou-Sellin R (1980) Somatomedins. N Engl J Med 302: 438-445

8. Grant M, Russell B, Fitzgerald C, Merimée TJ (1986) Insulin-like growth factors in vitreous. Studies in control and diabetic subjects with neovascularization. Diabetes 35: 416-420

9. Krolewski AS, Warram JH, Rand LI, Christlieb AR, Busick J, Kahn CR (1986) Risk of proliferative diabetic retinopathy in juvenile-onset type I diabetes: 40-yr. follow-up study. Diabetes Care 9: 443-452 
10. Sjöberg S, Gunnarsson R, Gjötterberg M, Lefvert AK, Persson A, Östman J (1987) Residual insulin production, glycaemic control and prevalence of microvascular lesions and polyneuropathy in long-term Type 1 (insulin-dependent) diabetes mellitus. Diabetologia 30: 208-213

11. Thorell J, Johansson B (1971) Enzymatic iodination of polypeptides with ${ }^{125} \mathrm{I}$ to high specific activity. Biochim Biophys Acta 25 : 360-369

12. Hall K, Brandt J, Enberg G, Fryklund L (1979) Immunoreactive somatomedin A in human serum. J Clin Endocrinol Metab 48: 271-278

13. Furlanetto RW, Underwood LE, Van Wyk J, D’Ercole AJ (1977) Estimation of somatomedin $C$ levels in normals and patients with pituitary disease by radioimmunoassay. J Clin Invest 60:648-657

14. Daughaday WH, Mariz I, Blethen SL (1980) Inhibition of bound somatomedin to membrane receptor and immunobinding sites: a comparison of radioreceptor and radioimmunoassay of somatomedin in native and acid-ethanol extracted serum. J Clin Endocrinol Metab 51: 781-788

15. Hansson HA, Rozell B, Skottner A (1987) Rapid axoplasmic transport of insulin-like growth factor I in the sciatic nerve of adult rats. Cell Tissue Res 247: 241-247

16. Scatchard G (1949) The attractions of proteins for small molecules and ions. An NY Acad Sci $51 ; 660-672$

17. Povoa G (1986) Somatomedin-binding protein. Isolation, determination, and studies of its regulation. Dissertation. Repro Print $A B$, Stockholm, pp 1-31

18. Amiel SA, Sherwin RS, Hintz RL, Gertner JM, Press CM, Tamborlane WV (1984) Effect of diabetes and its control in insulin-like growth factors in the young subject with type I diabetes. Diabetes 33: $1175-1179$
19. Tan K, Baxter RC (1986) Serum insulin-like growth factor I levels in adult diabetic patients: the effect of age. $\mathrm{J}$ Clin Endocrinol Metab 63: 651-655

20. Baxter RC, Martin JL (1986) Radioimmonoassay of growth-hormone dependent insulin-like growth factor binding protein in human plasma. J Clin Invest 504-512

21. Hall K, Hansson U, Lundin G, Luthman M, Persson B, Povoa G, Stangenberg M, Öfverholm U (1986) Serum levels of somatomedins and somatomedin - binding protein in pregnant women with type I or gestational diabetes and their infants. J Clin Endocrinol Metab 63: 1300-1306

22. Suikkari A, Koivisto VA, Rutanen EM, Yki-Järvinen $H$, Karonen SL, Seppälä M (1988) Insulin regulates the serum levels of low molecular weight insulin-like growth factor binding protein. J Clin Endocrinol Metab 66: 266-272

23. Elgin RG, Busby Jr WH, Clemmons DR (1987) An insulin-like growth factor (IGF) binding protein enhances the biological response to IGF I. Proc Natl Acad Sci USA 84: 3254-3258

Received: 21 October 1988

and in revised form: 17 July 1989

\section{Dr. P.Arner}

Department of Medicine

Huddinge Hospital

S-141 86 Huddinge

Sweden 